\title{
PENGARUH KEDALAMAN AIR KOLAM TADAH HUJAN TERHADAP KELANGSUNGAN HIDUP DAN PERTUMBUHAN IKAN LELE LOKAL (Clarias batrachus)
}

\author{
Mochamad Yunus*), Agus Priyadi*) dan Abdul Wahid ${ }^{*}$ )
}

\begin{abstract}
ABSTRAK
Ketersediaan air kolam tadah hujan sangat terbatas, sehingga mengakibatkan variasi suhu air harian cukup besar, dan akan berpengaruh terhadap ikan lele yang peka terhadap perubahan suhu yang cukup besar.

Penelitian ini bertujuan untuk mengetahui kedalaman air tertentu yang suhunya relatif stabil dan berpengaruh baik terhadap ikan lele, dengan melihat fluktuasi suhu air harian, kelangsungan hidup dan pertumbuhan bobot ikan, serta sifat kimia air.

Sembilan kolam tanah yang digunakan berukuran masing-masing $5 \times 5 \mathrm{~m}$, digunakan dalam penelitian. Benih lele lokal dengan bobot individu awal sekitar $4 \mathrm{~g}$ ditebar dengan kepadatan $20 \mathrm{ekor} / \mathrm{m}^{2}$. Ikan diberi pakan pelet tiga kali per hari sebanyak $3 \%$ bobot total ikan. Perlakuan yang diberikan adalah kedalaman air berbeda yaitu $50 \mathrm{~cm}, 100 \mathrm{~cm}$ dan $150 \mathrm{~cm}$.

Hasil penelitian menunjukkan bahwa fluktuasi suhu air harian menjadi relatif stabil dengan semakin dalam air kolam. Kedalaman air $100 \mathrm{~cm}$ lebih baik dari pada kedalaman air lainnya, dengan selisih kisaran suhu air harian rata-rata $3,5^{\circ} \mathrm{C}$. Pada kedalaman tersebut, bobot individu ikan rata-rata menjadi $26,3 \mathrm{~g}$ setelah pemeliharaan 3 bulan, dengan produksi rata-rata $3,99 \mathrm{~kg}$, derajat kelangsungan hidup rata-rata $46,1 \%$ dan konversi pakan 3,62.
\end{abstract}

\section{ABSTRACT: Effect of Water Depth in the Rainfed Ponds on the Survival and Growth of Local Catfish (Clarias batrachus), by: Mocbamad Yunus, Agus Priyadi and Abdul Wabid}

The availability of rainfed pond water is limited, causing large variation of daily water temperature that will affect the growth of catfish.

The aim of this research is to know the impact of water depth on the growth local catfish, by determining the daily fluctuation of water temperatures, survival and growth of fish, as well as the chemical condition of water.

Nine earthen ponds measuring $5 \times 5 \mathrm{~m}$ each used in this experiment. Local catfish fry of $4 \mathrm{~g}$ individual weight were stocked at a density of $20 \mathrm{fish} / \mathrm{m}^{2}$. Pelleted feed was given three times a day, at $3 \%$ biomass weight. The treatments were three different water depths i.e. $50 \mathrm{~cm}, 100 \mathrm{~cm}$ and $150 \mathrm{~cm}$.

The result showed that the daily water temperature become relatively stable in deeper ponds. The water depth $100 \mathrm{~cm}$ was trend to produce higher fish yield. In this water depth, individual fish grew to $26,3 \mathrm{~g}$ in 3 months rearing period, with average production of $3,99 \mathrm{~kg}$, average survival rate of $46,1 \%$, and feed coversion of 3,62 .

KEYWORDS: Rainfed ponds, survival and growth, Catfish

7) Peneliti pada Instalasi Penelitian Perikanan Air Tawar Depok 


\section{PENDAHULUAN}

Kolam tadah hujan termasuk dalam kategori lahan marginal bagi pengembangan budidaya ikan air tawar. Hal ini perlu dimanfaatkan khususnya dalam mengatasi kesulitan dalam mendapatkan lahan subur untuk budidaya ikan serta meningkatkan ekonomi, pangan dan gizi masyarakat sekitar lahan itu sendiri.

Dalam pemanfaatannya, perlu dipertimbangkan budidaya jenis-jenis ikan yang dapat berkembang baik pada kondisi perairan tadah hujan, yaitu jenisjenis ikan yang mempunyai daya toleransi yang cukup tinggi untuk hidup dan berkembang dalam perairan yang kualitasnya kurang baik.

Ikan lele (Clarias sp.) termasuk jenis ikan yang memiliki alat pernafasan tambahan (air breathing fish), sehingga mempunyai daya toleransi yang lebih baik dibanding jenis ikan lainnya terhadap kondisi lingkungan yang relatif kurang baik. Ikan ini merupakan salah satu jenis ikan ekonomis penting di Indonesia (Sidthimunka, 1972). Lele banyak dijumpai hidup di perairan rawa, sungai, sawah dan bahkan perairan yang sedikit payau (Smith, 1980), dan juga dalam air limbah (Sumastri dan Djajadiredja, 1982).

Kolam tadah hujan ketersediaan airnya sangat terbatas dengan variasi suhu cukup besar terutama antara saat hujan dan tidak hujan. Hal ini berpengaruh pada ikan lele yang peka terhadap perubahan suhu.

Sehubungan dengan hal di atas, sebagai salah satu upaya untuk memperkecil variasi suhu harian, dapat dilakukan dengan memperbesar volume air per satuan luas, antara lain dengan memperdalam air kolam. Pemeliharaan ikan lele lokal dalam kolam tembok secara intensif, menunjukkan adanya pengaruh kedalaman air terhadap pertumbuhan, derajat kelangsungan hidup dan efisiensi pakan ikan lele lokal (Jangkaru et al., 1991). Penelitian lainnya yang berhubungan pula dengan volume air telah dilakukan dalam keramba jaring apung di waduk Cirata oleh Yuliati et al. (1991). Dengan sistem tersebut ikan lele dengan bobot individu awal rata-rata 3,17 g tumbuh menjadi $100 \mathrm{~g}$ selama 6 bulan, dengan mortalitas sangat rendah (1,6-7,0\%). Data di atas baru merupakan hasil dari penelitian dalam kolam tembok dan waduk, sedangkan untuk kolam tanah terutama kolam tadah hujan belum diperoleh. Untuk itu suatu penelitian terhadap kedalaman air berbeda di kolam tanah di daerah tadah hujan dilakukan guna mengetahui kedalaman air optimal yang dapat mempertahankan kestabilan suhu sehingga berpengaruh baik terhadap ikan lele yang dipelihara di dalamnya.

\section{BAHAN DAN METODE}

Penelitian menggunakan 9 kolam tanah dengan luas masing-masing $25 \mathrm{~m}^{2}$, di Balai Penelitian Perikanan Air Tawar, Sukamandi. Perlakuan dengan tiga ulangan dalam Rancangan Acak Lengkap (RAL) terdiri kedalaman air $50 \mathrm{~cm}$, $100 \mathrm{~cm}$ dan $150 \mathrm{~cm}$. 
Benih ikan lele lokal dengan bobot individu sekitar 4 gram ditebar dengan kepadatan 20 ekor $/ \mathrm{m}^{2}$. Ikan diberi pakan pelet tiga kali per hari sebanyak $5 \%$ selama tiga minggu pertama, $4 \%$ selama tiga minggu kedua dan seterusnya $3 \%$ hingga panen. Pelet yang diberikan mengandung $25 \%$ protein, $5 \%$ lemak, $5 \%$ serat dengan kadar air $12 \%$.

Pengambilan contoh ikan sebayak 10\% dilakukan setiap 3 minggu untuk mengetahui pertumbuhan bobot individunya. Pengukuran setiap 3 minggu dimaksudkan agar ikan tidak terlalu banyak mengalami stress dibandingkan bila dilakukan setiap 2 minggu, karena ukuran ikan yang masih cukup kecil. Analisa kualitas air dilakukan setiap tiga minggu yang meliputi analisa kadar $\mathrm{O}_{2}, \mathrm{CO}_{2}, \mathrm{pH}$, alkalinitas dan amoniak total, dengan menggunakan metoda titrasi biasa. Pengamatan suhu air dilakukan setiap hari untuk mengetahui fluktuasi hariannya, dengan menggunakan termometer maksimum-minimum yang diletakkan $20 \mathrm{~cm}$ di atas dasar kolam. Produksi dan kehilangan/kematian ikan dihitung pada waktu panen yaitu setelah masa pemeliharaan 3 bulan.

Penambahan air selain curah hujan dilakukan untuk mengganti kehilangan air kolam akibat penguapan dan perembesan.

Analisis statistik dari data hasil percobaan dilakukan dengan menggunakan analisis sidik ragam untuk rancangan acak lengkap dan uji Duncan.

\section{HASIL DAN PEMBAHASAN}

\section{Kisaran Suhu Air Harian}

Kisaran suhu air harian selama penelitian tercantum pada Table 1. Kisaran suhu air harian terbesar terjadi pada kolam dengan kedalaman air $50 \mathrm{~cm}$ dengan selisih kisaran $4,2^{\circ} \mathrm{C}$. Besarnya selisih kisaran suhu cenderung mengecil dengan meningkatnya kedalaman air. Pada kedalaman air $100 \mathrm{~cm}$, selisih kisarannya menjadi $3,5^{\circ} \mathrm{C}$ dan pada kedalaman $150 \mathrm{~cm}$ hanya $2,4^{\circ} \mathrm{C}$.

Table 1. Water temperature ranges in different water depths of rainfed fish ponds

\begin{tabular}{cccccr}
\hline \hline \multirow{2}{*}{$\begin{array}{l}\text { Water } \\
\text { depth }\end{array}$} & \multicolumn{5}{c}{ Temperature $\rho \mathrm{C})$} \\
\cline { 2 - 5 }$(\mathrm{cm})$ & \multicolumn{2}{c}{ Maximum } & \multicolumn{2}{c}{ Minimum } & \multicolumn{2}{c}{$\begin{array}{c}\text { Difference of } \\
\text { Min-Max }\end{array}$} \\
\cline { 2 - 5 } & Means & Range & Means & Range & \\
\hline 50 & 31,3 & $28,7-33,3$ & 27,3 & $26,0-28,7$ & $4,2^{a}$ \\
100 & 30,6 & $28,7-33,7$ & 27,1 & $26,0-29,0$ & $3,5^{a b}$ \\
150 & 29,9 & $28,0-32,7$ & 27,5 & $26,0-29,0$ & $2,4^{b}$ \\
\hline \hline
\end{tabular}

Note: The same notation indicates statistically not different $(P>0.05)$ 
Analisis keragaman terhadap selisih kisaran suhu air harian menunjukkan adanya perbedaan yang nyata $(\mathrm{P}<0,05)$, yang terjadi antara kedalaman air 50 $\mathrm{cm}$ dengan $150 \mathrm{~cm}$ (uji Duncan). Keadaan ini menunjukkan adanya pengaruh kedalaman air terhadap fluktuasi suhu air harian.

Suhu air maksimum dan minimum yang paling banyak terjadi (modus) pada kedalaman air $50 \mathrm{~cm}$ adalah $30,2^{\circ} \mathrm{C}$ dan $26,5^{\circ} \mathrm{C}$, pada kedalaman $100 \mathrm{~cm}$ adalah $29,7^{\circ} \mathrm{C}$ dan $26,8^{\circ} \mathrm{C}$ dan pada kedalaman $150 \mathrm{~cm}$ adalah $29,6^{\circ} \mathrm{C}$ dan $27,2^{\circ} \mathrm{C}$. Nilai-nilai suhu tersebut termasuk ke dalam kisaran yang baik untuk ikan.

Berdasarkan pada selisih kisarannya, yaitu pada kedalaman $100 \mathrm{~cm}$ tidak berbeda nyata dengan selisih pada kedalaman $150 \mathrm{~cm}$, dan juga keadaan modusnya, dapat dikatakan bahwa kedalaman air $100 \mathrm{~cm}$ merupakan kedalaman air optimal. Hal ini sejalan dengan pernyataan Soeyanto (1987) bahwa kedalaman air untuk usaha pembesaran ikan lele berkisar antara $80-100 \mathrm{~cm}$.

\section{Bobot Individu Ikan}

Bobot individu ikan yang diamati pada setiap pengambilan contoh tercantum pada Table 2. Kenaikan bobot individu ikan pada perlakuan kedalaman air $150 \mathrm{~cm}$ sedikit lebih tinggi dari pada perlakuan lainnya. Hasil analisis sidik ragam terhadap pertumbuhan bobot ikan menunjukkan perbedaan tidak nyata, yang menunjukkan tidak adanya pengaruh kedalaman air terhadap pertumbuhan bobot individu ikan.

Table 2. Average body weight $(g)$ of fish in different water deptbs of rainfed fishponds in every sampling periods

\begin{tabular}{cccccc}
\hline \hline $\begin{array}{l}\text { Water } \\
\text { deptb }\end{array}$ & \multicolumn{5}{c}{ Individuals weight $(\mathrm{g})$} \\
\cline { 2 - 6 }$(\mathrm{cm})$ & 0 & 3 & 6 & 9 & 12 \\
\hline 50 & $4,01^{a}$ & $6,72^{b}$ & $11,3^{c}$ & $20,5^{d}$ & $26,3^{e}$ \\
100 & $4,08^{a}$ & $6,62^{b}$ & $11,6^{c}$ & $20,1^{d}$ & $26,3^{e}$ \\
150 & $4,02^{a}$ & $7,52^{b}$ & $14,7^{c}$ & $22,0^{d}$ & $28,6^{c}$ \\
\hline \hline
\end{tabular}

Note: The same notation indicates statistically not different $(P>0.05)$

Keadaan tersebut di atas disebabkan karena energi yang digunakan ikan lele untuk mengambil oksigen dari udara pun menjadi lebih besar walaupun variasi suhu air harian menjadi lebih stabil dengan semakin dalamnya perairan. Dengan demikian pada kedalaman air yang lebih dalam energi dari pelet yang dimakan ikan lebih banyak digunakan untuk pergerakan ke permukaan. 
Keadaan di atas ditunjukkan pula pada pemeliharaan ikan lele lokal dalam kolam tembok secara intensif, dengan tiga kedalaman air yang berbeda yaitu $25 \mathrm{~cm}, 50 \mathrm{~cm}$ dan $100 \mathrm{~cm}$. Pada penelitian tersebut walaupun ikan lele tumbuh lebih baik pada kedalaman air $100 \mathrm{~cm}$, namun tidak berbeda nyata dengan pada kedalaman $50 \mathrm{~cm}$, tetapi berbeda nyata dengan pertumbuhan pada kedalaman $25 \mathrm{~cm}$ (Jangkaru et al., 1991).

\section{Derajat Kelangsungan Hidup}

Derajat kelangsungan hidup ikan selama masa pemeliharaan 3 bulan tercantum pada Table 3. Derajat kelangsungan hidup antar perlakuan relatif sama. Analisis sidik ragam menunjukkan perbedaan tidak nyata $(P>0,05)$, yang memperlihatkan tidak berpengaruhnya perbedaan kedalaman air pada derajat kelangsungan hidup ikan. Rendahnya derajat kelangsungan hidup ikan pada semua perlakuan, disebabkan karena kualitas air yang kurang baik terutama kadar amoniak (Table 6).

Table 3. Survival rate of catfish (\%) during 3 months of growing period

\begin{tabular}{ccc}
\hline \hline \multirow{2}{*}{$\begin{array}{c}\text { Water deptb } \\
(\mathrm{cm})\end{array}$} & \multicolumn{2}{c}{ Survival rate (\%) } \\
\cline { 2 - 3 } & Means & Range \\
\hline 50 & $41,9^{a}$ & $37,0-49,6$ \\
100 & $46,1^{a}$ & $39,4-53,0$ \\
150 & $44,9^{a}$ & $42,4-48,2$ \\
\hline \hline
\end{tabular}

Note: The same notation indicates statistically not different $(P>0.05)$

Keadaan ini juga terjadi pada pemeliharaan ikan lele dalam kolam tembok. Derajat kelangsungan hidup ikan pada kedalaman $100 \mathrm{~cm}$ dan $50 \mathrm{~cm}$ tidak berbeda nyata. Perbedaan nyata hanya terjadi antara kedalaman 50 dan $100 \mathrm{~cm}$ (masing-masing 96\%) dengan derajat kelangsungan hidup pada kedalaman 25 $\mathrm{cm}$ yaitu 85\% (Jangkaru et al., 1991).

\section{Produksi Ikan}

Produksi ikan setelah masa pemeliharaan 3 bulan tercantum dalam Table 4. Produksi ikan cenderung meningkat dengan semakin dalamnya perairan. Namun demikian hasil analisis keragamannya menunjukkan perbedaan produksi yang tidak nyata $(P>0.05)$, seperti halnya terjadi terhadap pertumbuhan bobot individunya. Dengan demikian dapat dikatakan bahwa perbedaan kedalaman air dari 50 sampai dengan $150 \mathrm{~cm}$ tidak berpengaruh terhadap produksi ikan lele lokal. 
Table 4. Production $(\mathrm{kg})$ of fish after 3 months rearing period

\begin{tabular}{ccc}
\hline \hline \multirow{2}{*}{$\begin{array}{c}\text { Water depth } \\
(\mathrm{cm})\end{array}$} & \multicolumn{2}{c}{ Production (kg) } \\
\cline { 2 - 3 } & Means & Range \\
\hline 50 & $3,481^{a}$ & $3,128-4,186$ \\
100 & $3,990^{a}$ & $3,403-4,927$ \\
150 & $4,418^{a}$ & $3,923-5,011$ \\
\hline \hline
\end{tabular}

Note: The same notation indicates statistically not different $(P>0.05)$

Pada penelitian di dalam kolam tembok, produksi ikan pada kedalaman air $50 \mathrm{~cm}$ mencapai $711 \mathrm{~g} / \mathrm{m}^{2}$ setelah masa pemeliharaan 4 bulan berbeda nyata dengan pada kedalaman air $25 \mathrm{~cm}\left(399 \mathrm{~g} / \mathrm{m}^{2}\right)$, tetapi tidak berbeda dengan kedalaman air $100 \mathrm{~cm}$ yaitu $805 \mathrm{~g} / \mathrm{m}^{2}$ (Jangkaru et al., 1991).

\section{Konversi Pakan}

Konversi pakan untuk setiap perlakuan tercantum pada Table 5.

Table 5. Feed conversion rates after 3 months of rearing period

\begin{tabular}{ccc}
\hline \hline \multirow{2}{*}{$\begin{array}{c}\text { Water deptb } \\
(\mathrm{cm})\end{array}$} & \multicolumn{2}{c}{ Conversion factor } \\
\cline { 2 - 3 } & Means & Range \\
\hline 50 & $4,12^{a}$ & $3,36-4,50$ \\
100 & $3,62^{a}$ & $2,86-4,13$ \\
150 & $3,79^{a}$ & $3,31-4,23$ \\
\hline \hline
\end{tabular}

Note: The same notation indicates statistically not different $(P>0.05)$

Konversi pakan pada perlakuan kedalaman air $50 \mathrm{~cm}$ relatif lebih tinggi dari perlakuan lainnya, sedangkan antar kedalaman $100 \mathrm{~cm}$ dan $150 \mathrm{~cm}$ relatif sama. Hasil analisis sidik ragam dari konversi pakan tersebut menunjukkan perbedaan yang tidak nyata $(P>0,05)$. Sehingga dapat dikatakan bahwa konversi pakan tidak dipengaruhi oleh kedalaman air. Pada penelitian di dalam kolam tembok, konversi pakan pada kedalaman air $50 \mathrm{~cm}(2,52)$ juga tidak berbeda nyata dengan kedalaman air $100 \mathrm{~cm}(2,24)$, tetapi berbeda nyata dengan kedalaman air $25 \mathrm{~cm}$ yaitu 3,63 (Jangkaru et al., 1991). 


\section{Kualitas Air}

Kisaran parameter kualitas air selama penelitian tercantum pada Table 6 . Kadar oksigen terlarut kisarannya cukup besar, tetapi nilai terendahnya masih berada di atas nilai ambang yang membahayakan bagi kehidupan ikan. Kadar karbon-dioksida bebas, kisarannya relatif kecil dengan nilai yang baik bagi kehidupan ikan. Demikian pula untuk $\mathrm{pH}$, nilainya berkisar di sekitar $\mathrm{pH}$ normal. Alkalinitas total menunjukkan keadaan perairan dengan produktivitas sedang. Amoniak totalnya berada pada kisaran di atas $0,1 \mathrm{mg} / 1$ yang dianggap sudah tidak baik untuk kehidupan ikan.

Tabel 6. Ranges of water quality parameters in rainfed fishponds during experiment

\begin{tabular}{crccc}
\hline \hline \multirow{2}{*}{ Parameters } & & \multicolumn{3}{c}{ Water depth (cm) } \\
\cline { 3 - 5 } & & 50 & 100 & 150 \\
\hline $\mathrm{O}_{2}$ & $(m g / l)$ & $2,1-8,6$ & $3,1-9,5$ & $2,6-7,9$ \\
$\mathrm{CO}_{2}$ & $(m g / l)$ & $5,2-8,2$ & $5,2-7,2$ & $5,4-7,6$ \\
$\mathrm{pH}$ & & $6,7-7,5$ & $6,6-7,3$ & $7,4-8,8$ \\
Total alkalinity & $m g \mathrm{CaCO} / \mathrm{l}$ & $41,9-44,3$ & $41,3-43,9$ & $30,2-35,3$ \\
$\mathrm{~N}-\mathrm{NH}_{3}$ & $(m g / l)$ & $0,26-0,37$ & $0,29-0,31$ & 0,46 \\
\hline \hline
\end{tabular}

\section{KESIMPULAN}

- Kedalaman air antara 50 sampai dengan $150 \mathrm{~cm}$ berpengaruh terhadap fluktuasi suhu air harian kolam tadah hujan, akan tetapi tidak berpengaruh nyata terhadap pertumbuhan bobot individu dan produksi ikan lele.

- Fluktuasi suhu air harian menjadi relatif stabil dengan semakin dalamnya air kolam. Kedalaman air $100 \mathrm{~cm}$ dianggap lebih baik dari pada kedalaman air 50 dan $150 \mathrm{~cm}$. Kedalaman air $150 \mathrm{~cm}$ mempunyai potensi yang lebih baik dilihat dari kecilnya fluktuasi suhu air harian, namun kurang menguntungkan dari segi penghematan energi bagi ikan lele yang bersifat mengambil $\mathrm{O}_{2}$ dari permukaan air.

- Setelah pemeliharaan selama 3 bulan pada kedalaman air $100 \mathrm{~cm}$, benih lele lokal dengan bobot individu awal $4 \mathrm{~g}$ tumbuh menjadi $26,3 \mathrm{~g}$, dengan produksi $3,99 \mathrm{~kg}$, derajat kelangsungan hidup 46,1\% dan konversi pakan 3,62 . 


\section{DAFTAR PUSTAKA}

Jangkaru, Z., M. Sulhi, Rusmaedi, M. Yunus dan E. Nurfitriana. 1991. Pengaruh kedalaman air terhadap pertumbuhan ikan lele (Clarias batrachus) yang dipelihara secara intensif dalam bak beton. Bull. Penel. Perik. Darat, Vol.10 No.1: 60-63. Balai Penelitian Perikanan Air Tawar, Bogor.

Sidthimunka, A. 1972. The culture of Pla Duk. Inland Fisheries Division. Departement of Fisheries Bangkok. Thailand. Report No. 12.

Smith, L.S. 1980. Digestion and teleost fishes. Fish Feed Technology. UNDP/ FAO, Rome, p.3-18.

Sumastri, S. dan R. Djajadiredja. 1982. Penelitian pendahuluan pembenihan ikan lele (Clarias batrachus) secara alami. Pewarta BPPD No.1: 26-29. Balai Penelitian Perikanan Darat Bogor.

Suyanto, R. 1987. Petunjuk praktis budidaya lele Afrika. Infis Manual seri No.57 Dit. Jen. Perikanan. Jakarta.

Yuliati, P., O. Praseno dan L. Dharma. 1991. Pembesaran Ikan Lele (Clarias batracbus) dalam keramba jaring apung. Bull. Penel. Perik. Darat Vol.10 No.3: 47-51. Balai Penelitian Perikanan Air Tawar, Bogor. 